\title{
High-Pressure Solubility of Carbon Dioxide in 1-Butyl-3-methylpiperidinium Bis(trifluoromethylsulfonyl)imide Ionic Liquid
}

\author{
Sang-Kyu Nam and Byung-Chul Lee ${ }^{\star}$ \\ Department of Chemical Engineering, Hannam University, 1646 Yuseongdaero, \\ Yuseong-gu, Daejeon 305-811, Korea \\ (Received February 17, 2014; Revised March 7, 2014; Accepted March 7, 2014)
}

\section{1-Butyl-3-methylpiperidinium Bis(trifluoromethylsulfonyl)imide 이온성 액체에 대한 이산화탄소의 고압 용해도}

\author{
남상규・이병철 \\ 한남대학교 화학공학과
}

(2014. 2. 17. 접수, 2014. 3. 7. 수정, 2014. 3. 7. 승인)

\begin{abstract}
Solubility data of carbon dioxide $\left(\mathrm{CO}_{2}\right)$ in 1-butyl-3-methylpiperidinium bis(trifluoromethylsulfonyl)imide ([bmpip][Tf $\left.{ }_{2} \mathrm{~N}\right]$ ) ionic liquid are presented at pressures up to about $30 \mathrm{MPa}$ and at temperatures between 303 $\mathrm{K}$ and $343 \mathrm{~K}$. As far as we know, the data on the $\mathrm{CO}_{2}$ solubility in the [bmpip][Tf $\left.{ }_{2} \mathrm{~N}\right]$ ionic liquid have never been reported in the literature by other investigators. The solubilities of $\mathrm{CO}_{2}$ were determined by measuring the bubble point or cloud point pressures of the $\mathrm{CO}_{2}+\left[\right.$ bmpip][Tf $\left.{ }_{2} \mathrm{~N}\right]$ mixtures with various compositions using a high-pressure equilibrium apparatus equipped with a variable-volume view cell. To observe the effect of the cation composing the ionic liquid on the $\mathrm{CO}_{2}$ solubility, the $\mathrm{CO}_{2}$ solubilities in [bmpip][Tf $\mathrm{T}_{2} \mathrm{~N}$ used in this study were compared with those in 1-butyl-3-methylimidazolium bis(trifluoromethylsulfonyl)-imide ([bmim][Tf $\left.\left.{ }_{2} \mathrm{~N}\right]\right)$. As the equilibrium pressure increased, the $\mathrm{CO}_{2}$ solubility in [bmpip][Tf $\left.{ }_{2} \mathrm{~N}\right]$ increased sharply. On the other hand, the $\mathrm{CO}_{2}$ solubility decreased with increasing temperature. The mole fraction-based $\mathrm{CO}_{2}$ solubilities were almost the same for both [bmpip][Tf $\left.{ }_{2} \mathrm{~N}\right]$ and $[\mathrm{bmim}]\left[\mathrm{Tf}_{2} \mathrm{~N}\right]$, regardless of temperature and pressure. The phase equilibrium data for the $\mathrm{CO}_{2}+\left[\right.$ bmpip][Tf $\left.f_{2} \mathrm{~N}\right]$ systems have been correlated using the Peng-Robinson equation of state.

요 약: 1-Butyl-3-methylpiperidinium bis(trifluoromethylsulfonyl)imide ([bmpip][Tf $\left.\mathrm{T}_{2} \mathrm{~N}\right]$ ) 이온성 액체를 대상 으로 약 $303 \mathrm{~K}$ 로부터 약 $343 \mathrm{~K}$ 의 온도 범위와 약 $30 \mathrm{MPa}$ 까지의 압력 범위에서 이온성 액체에 녹는 이 산화탄소 $\left(\mathrm{CO}_{2}\right)$ 의 용해도를 측정하였다. 우리가 아는 한, [bmpip][Tf $\left.2 \mathrm{~N}\right]$ 에 대한 $\mathrm{CO}_{2}$ 의 용해도 데이터는 다른 연구자들에 의해 지금까지 문헌에 발표된 바가 없다. 가변부피투시창 (variable-volume view cell)이 장착된 고압용 상평형 장치를 사용하여 온도를 변화시키면서 여러 가지 조성을 갖는 $\mathrm{CO}_{2}+[\mathrm{bmpip}]\left[\mathrm{Tf}_{2} \mathrm{~N}\right]$ 혼합물의 기포점 또는 구름점 압력을 측정함으로써 [bmpip][Tf $\left.{ }_{2} \mathrm{~N}\right]$ 에서의 고압 $\mathrm{CO}_{2}$ 의 용해도를 결정하였 다. 이온성 액체가 가지고 있는 양이온이 $\mathrm{CO}_{2}$ 용해도에 미치는 영향을 관찰하기 위하여, 본 연구에서 사용
\end{abstract}

$\star$ Corresponding author

Phone : +82-(0)42-629-8838 Fax : +82-(0)42-629-8835

E-mail : bclee@hannam.kr 
한 [bmpip][Tf $\left.{ }_{2} \mathrm{~N}\right]$ 에 대한 $\mathrm{CO}_{2}$ 용해도 데이터를 1-butyl-3-methylimidazolium bis(trifluoromethylsulfonyl)imide ([bmim] [Tf $\left.{ }_{2} \mathrm{~N}\right]$ )에 대한 $\mathrm{CO}_{2}$ 용해도 데이터와 비교하였다. 압력이 증가함에 따라 [bmpip][Tf $\left.{ }_{2} \mathrm{~N}\right]$ 에 대한 $\mathrm{CO}_{2}$

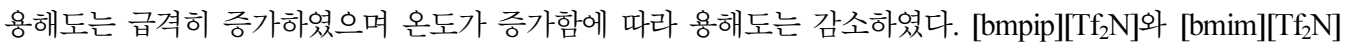
두 이온성 액체에 대하여 $\mathrm{CO}_{2}$ 의 용해도는 몰분율 기준으로 온도 및 압력 조건에 관계없이 거의 같았다. Peng-Robinson 상태 방정식을 사용하여 $\mathrm{CO}_{2}+[\mathrm{bmpip}]\left[\mathrm{Tf} \mathrm{f}_{2} \mathrm{~N}\right]$ 혼합물 시스템에 대한 상평형 모델링을 수행 하였다.

Key words: ionic liquid, carbon dioxide, solubility, piperidinium, thermodynamic modeling, Peng-Robinson equation of state

\section{1. 서 론}

대기에서의 이산화탄소 $\left(\mathrm{CO}_{2}\right)$ 농도의 증가와 온실효 과 간의 상관관계는 $\mathrm{CO}_{2}$ 및 다른 온실가스의 배출 감 소를 향한 전 세계적인 논쟁을 촉발시켰다. $\mathrm{CO}_{2}$ 배출 은 산업혁명 이래 증가되어 왔으며, 이는 대기에서의 $\mathrm{CO}_{2}$ 농도를 산업화 전 $280 \mathrm{ppm}$ 으로부터 오늘날 390 $\mathrm{ppm}$ 으로 증가시켰다. 2008 년 기준 지구의 $\mathrm{CO}_{2}$ 배출은 약 $29.4 \mathrm{Gt}$ 이었는데, 이는 1990 년의 $20.9 \mathrm{Gt}$ 과 비교하 면 약 $40 \%$ 의 증가에 해당한다. 현재 발전 부문이 모든 에너지 관련 $\mathrm{CO}_{2}$ 배출 중 $41 \%$ 를 차지하고 있으며, 그 다음으로 수송 부문 $(23 \%)$, 산업 부문 $(20 \%)$, 건물 부 문 $(10 \%)$ 순이다. ${ }^{1}$ 발전 부문에서의 $\mathrm{CO}_{2}$ 배출 중 높은 비중을 차지하는 것이 전기나 열을 발생시키기 위한 연료 연소와 관련이 있다. 2008년 기준 연료 연소로부 터의 전체 $\mathrm{CO}_{2}$ 배출에서 석탄이 차지하는 비중이 $43 \%$ 였으며, 반면에 석유와 가스가 차지하는 비중은 각각 $37 \%$ 와 $20 \%$ 였다. 앞으로 $\mathrm{CO}_{2}$ 배출량은 계속 증가할 것 이며 2050년까지 2007년 배출량인 $28.8 \mathrm{Gt}$ 의 두 배가 될 것으로 전망된다. ${ }^{1}$ 따라서 장기적으로 화석연료로부 터 저탄소 기술로의 에너지 경로의 전환이 요구된다. 그러나 가까운 장래에는 화석연료, 특히 석탄은 계속해 서 에너지 포트폴리오의 상당한 부분이 될 것이다. 이러 한 점에서 $\mathrm{CO}_{2}$ 포집 및 저장 $\left(\mathrm{CO}_{2}\right.$ capture and storage, $\mathrm{CCS})$ 은 반드시 필요하다.

$\mathrm{CCS}$ 는 기술적으로 도전적이며, 상용화되기 위해서 는 많은 장애물들이 극복되어야 한다. ${ }^{1,2} \mathrm{CCS}$ 공정을 대규모로 상용화시킬 때 부딪치는 주요 장벽은 분리 방법과 관련된 에너지/비용이다. 현재 가능한 $\mathrm{CO}_{2}$ 포 집 기술은 amine 용매, 예를 들어 monoethanolamine (MEA)에 기반하고 있다. ${ }^{3}$ Amine을 사용한 $\mathrm{CO}_{2}$ 포집 은 반응 엔탈피가 큰 화학반응을 포함하기 때문에, 재 생 단계에서 포집된 $\mathrm{CO}_{2}$ 를 방출시키기 위해 많은 양
의 열이 필요하게 된다. 기존의 발전 플랜트에 전통적 인 amine 용매를 사용하는 CCS 설비를 새로 장착하 면 플랜트의 에너지 생산량이 25 40\%까지 감소된다 고 예측하고 있다. ${ }^{2}$

효율적인 $\mathrm{CO}_{2}$ 제거를 위해 가능한 여러 가지 방법들 중에서 alkanolamine 수용액을 사용한 흡수 방법이 오랫 동안 이용되어 왔으며 지금까지 가장 효율적인 것이었 다. 그러나 용매 손실과 alkanolamine의 높은 재생 비용 으로 인해 신기술 및 대체기술을 찾으려는 연구들이 진 행되어왔다. 최근에 $\mathrm{CO}_{2}$ 를 포집하기 위한 유망한 후보 물질로 이온성 액체가 부상하고 있는데, 이는 이온성 액체가 가지는 우수한 물성 때문이다. 이온성 액체는 약 $100{ }^{\circ} \mathrm{C}$ 이하에서 액체로 거동하는 유기염의 일종에 속하며, 보통 큰 유기 양이온이 더 작은 크기의 유기 음 이온 또는 무기 음이온과 결합된 형태로 구성된다. 이 온성 액체를 구성하는 양이온과 음이온의 다양한 결합 으로 이온성 액체의 성질을 조절함으로써 반응과 분리 에 필요한 더 우수한 용매를 설계할 수 있게 된다.

지난 10 여 년 동안의 다양한 실험적 연구를 통하여 이온성 액체가 매우 낮은 휘발성(무시할만한 증기압), 넓은 액체 범위, 기체에 대한 높은 용해도, 우수한 열 안정성 및 이온 전도성과 같은 흥미롭고 관심을 끄는 열물성을 보여주는 것으로 보고되었다. 이 연구 결과 들을 살펴보면 이온성 액체가 보여주는 열물성들은 다른 일반 액체가 가지는 열물성들과 차별화된다는 것을 알 수 있다. 이러한 이유로 이온성 액체들이 여 러 응용분야에서 특히 관심을 끌고 있다. ${ }^{4}$ 특히 탈황 공정과 같은 물리 흡수 공정에서 일반적으로 사용되 는 기체 분리제의 유망한 대체 용매로 이온성 액체가 최근에 주목을 받고 있다. ${ }^{5,6}$ 또한 기체 분리 매체로 이온성 액체는 다른 기체들에 비해 특히 잘 용해시키 는 $\mathrm{CO}_{2}$ 의 포집에서도 매우 유망해 보인다. ${ }^{7}$

이온성 액체는 압력이 증가함에 따라 $\mathrm{CO}_{2}$ 흡수능 
이 증가하는 물리 흡수제의 특성을 가지고 있다. 따라 서 고압에서 운전이 가능한 연소 전 $\mathrm{CO}_{2}$ 포집공정에 유리하다. 연소 전 $\mathrm{CO}_{2}$ 포집기술은 석탄의 가스화 또 는 천연가스의 개질반응에 의한 합성가스 (주로 $\mathrm{CO}$, $\mathrm{CO}_{2}, \mathrm{H}_{2}$ )를 생산한 후, 수성가스 전이반응을 통해 $\mathrm{CO}$ 를 $\mathrm{H}_{2}$ 와 $\mathrm{CO}_{2}$ 로 전환시키고 $\mathrm{CO}_{2}$ 를 포집하는 기술이다. 이는 $\mathrm{CO}_{2}$ 를 고압 $(2 \sim 6 \mathrm{MPa})$ 에서 포집하고 저압에서 회수하는 기술이다. 따라서 $\mathrm{CO}_{2}$ 분리 시 에너지 소비 가 낮아 분리 비용을 크게 줄일 수 있다는 장점을 가 지고 있다. 따라서 비수용성인 이온성 액체 흡수제를 이 기술에 이용한다면 혁신적으로 $\mathrm{CO}_{2}$ 포집 비용을 줄일 수 있다는 장점을 가지고 있다.

흡수 용매로 가장 적합한 이온성 액체를 찾기 위해서 반드시 알아야 하는 데이터가 이온성 액체에 대한 기체 의 용해도이다. 최근에 다양한 온도와 압력 조건에서 이 온성 액체에 대한 $\mathrm{CO}_{2}$ 의 용해도를 다루는 상당한 양의 실험적 연구결과들이 문헌에 보고되었다.,8-21 이러한 연 구결과들을 자세히 분석해보면 imidazolium 계열의 양 이온과 $\left[\mathrm{Tf}_{2} \mathrm{~N}\right]$ 계열의 음이온을 갖는 이온성 액체가 가 장 높은 $\mathrm{CO}_{2}$ 용해도를 보여주는 것으로 나타났다.22 이 온성 액체에 대한 $\mathrm{CO}_{2}$ 의 용해도가 광범위하게 측정되 었을지라도 기체 흐름으로부터 $\mathrm{CO}_{2}$ 를 포집하기 위한 흡수 매체로서 이온성 액체를 사용하는 산업적인 적용 은 아직도 부족한 실정인데, 이는 아마도 몰랄 농도 기 준, 즉 이온성 액체 단위 질량 당 $\mathrm{CO}_{2}$ 의 몰 수 기준을 고려한다면 기체 흐름을 처리하기 위해서는 상당한 양 의 이온성 액체가 필요하기 때문이다. ${ }^{22,23}$ 이온성 액체에 대한 $\mathrm{CO}_{2}$ 의 용해도는 이온성 액체 단위 몰당 $\mathrm{CO}_{2}$ 의 몰 수 기준으로는 높지만 이온성 액체 단위 질량 당 $\mathrm{CO}_{2}$ 의 몰 수 기준으로는 높지 않다. 그럼에도 불구하고 상용공 정 scale-up 목적에 적합한 흡수 시스템을 합리적으로 설계하기 위해서는 $\mathrm{CO}_{2}$ 와 이온성 액체 간의 물리적 평 형에 대해 상세히 알아야 한다. 본 연구에서는 지금까지 상평형 데이터가 발표된 적이 없는 piperidinium 계열의 양이온과 [ $\left.\mathrm{Tf}_{2} \mathrm{~N}\right]$ 음이온으로 구성되어 있는 1-butyl-3methylpiperidinium bis(trifluoromethylsulfonyl)imide ([bmpip] [Tf $\left.{ }_{2} \mathrm{~N}\right]$ ) 이온성 액체를 대상으로 고압에서의 $\mathrm{CO}_{2}$ 의 용해도를 측정하였으며, 그 결과를 본 연구실에
서 이미 발표한 imidazolium 계열의 양이온을 갖는 이온 성 액체의 결과와 비교하였다.

이온성 액체를 포함하는 시스템의 상평형을 실험적 으로 측정하는 것은 비용이 많이 들고 시간도 많이 걸릴 수 있기 때문에 흡수 시스템의 운전 조건 내에 서 유효한 이온성 액체에서의 $\mathrm{CO}_{2}$ 용해도를 추산할 수 있는 수학적 모델을 갖는 것은 매우 바람직하다. 실제로, 이온성 액체에서의 기체 용해도의 모델링에 대한 다양한 접근방법들이 문헌에 보고되었다. ${ }^{24-29}$ 최 근에 Vega 등은 이온성 액체에 대한 기체 용해도를 포함하여 이온성 액체의 열물성을 모델링하기 위한 최신의 접근방법에 대한 종합적인 검토 결과를 발표 하였다. 3 차 상태 방정식은 혼합물의 상거동을 모델 링할 수 있는 가장 간단한 접근방법이며 더욱이 어떠 한 공정 모사기에서도 항상 이용할 수 있기 때문에, 상거동 모델링 분야에서는 3 차 상태 방정식을 사용 하는 것이 선호된다. ${ }^{21}$ 본 연구의 또 하나의 목적은 3 차의 상태 방정식인 Peng-Robinson 식을 사용하여 이 온성 액체에 대한 $\mathrm{CO}_{2}$ 의 용해도를 모델링하는 것이다.

\section{2. 실 험}

\section{1. 실험 재료}

본 연구에서 사용한 이온성 액체는 Sigma-Aldrich 사로부터 구입하였다. 이온성 액체 시료는 실험 전 용 해도 측정 실험을 위한 셀 안에 넣고 진공펌프를 이 용하여 상온에서 약 1 일 동안 진공을 걸어 주어 시료 에 남아 있을 수 있는 휘발성 물질이나 수분을 제거 하였다. 실험에 사용된 이온성 액체와 그 특성치를 Table 1에 나타내었다. 실험에 사용된 $\mathrm{CO}_{2}$ 는 명신가스 사로부터 구입하였으며 $99.99 \%$ 의 높은 순도를 가졌다. 이온성 액체와 이산화탄소 가스는 추가적인 정제 없이 그대로 사용하였다.

\section{2. 실험 장치 및 방법}

이온성 액체에 대한 $\mathrm{CO}_{2}$ 의 용해도를 측정하기 위 한 실험장치는 가변부피 투시 셀 (variable-volume view cell)이 장착되어 있는 고압 상거동 측정 장치로

Table 1. Ionic liquid studied in this work

\begin{tabular}{|c|c|c|c|c|c|}
\hline Chemical name & Abbreviation & $\begin{array}{c}\text { CAS } \\
\text { number }\end{array}$ & $\begin{array}{l}\text { Chemical } \\
\text { formula }\end{array}$ & $\begin{array}{l}\text { Molecular } \\
\text { mass }\end{array}$ & $\begin{array}{c}\text { Purity } \\
{[\text { mass \%] }}\end{array}$ \\
\hline $\begin{array}{l}\text { 1-butyl-1-methylpiperidinium } \\
\text { bis(trifluoromethylsulfonyl)imide }\end{array}$ & {$\left[\right.$ bmpip] $\left[\mathrm{Tf}_{2} \mathrm{~N}\right]$} & $623580-02-9$ & $\mathrm{C}_{12} \mathrm{H}_{22} \mathrm{~F}_{6} \mathrm{~N}_{2} \mathrm{O}_{4} \mathrm{~S}_{2}$ & 436.44 & $\geq 96.5$ \\
\hline
\end{tabular}

Vol. 27, No. 2, 2014 

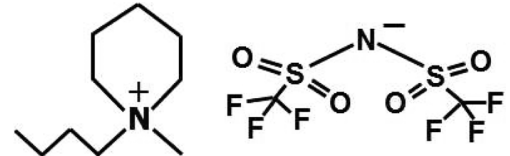

Fig. 1. Chemical structure of ionic liquid [bmpip][Tf $2 \mathrm{~N}]$.

서 장치의 개략도를 Fig. 2에 나타내었다. 본 실험 장 치와 실험 방법에 대한 상세한 묘사는 본 연구실에서 발표한 다른 논문에도 설명되어 있다. ${ }^{16-20}$ 이 장치 중 가장 핵심적인 부분인 가변부피 투시 셀은 내경 16 $\mathrm{mm}$ 와 외경 $70 \mathrm{~mm}$ 의 크기와 약 $31 \mathrm{~cm}^{3}$ 의 내부 부피 를 가진 실린더 모양의 고압용기이다. 셀의 부피를 변 화시키기 위하여 셀 안에 피스톤이 설치되어 있으며, 셀 내부를 관찰할 수 있도록 셀의 한쪽에 사파이어 투시 창 (sapphire window)이 설치되어 있다. Pressure generator (High Pressure Equipment Co. model 50-6$15)$ 는 물을 압축시켜 피스톤을 이동시킴으로서 셀 내 부의 부피를 감소시켜 셀의 압력을 높이거나 낮추는 역할을 한다. 압력은 $\pm 0.05 \mathrm{MPa}$ 의 정밀도를 가진 정 밀 압력계(Dresser Heise model CC-12-G-A-02B)로 측 정하였으며, 실험 온도는 셀 내부로 연결한 RTD (Pt$100 \Omega$ )로 감지하여 $\pm 0.1 \mathrm{~K}$ 의 정확도로 측정하였다. 셀 의 온도는 온도조절장치가 부착된 강제순환식 air bath를 사용하여 일정하게 유지시켰다. Borescope (Olympus model R080-044-000-50)와 CCD 카메라 (WAT-202B)를 모니터에 연결하여 투시 창을 통해 셀 내부에서 일어나는 상거동을 육안으로 관찰하였으며, 셀 내부의 용액을 혼합시키기 위하여 셀의 아래쪽에 마그네틱 교반기를 설치하였다. 가변부피 투시 셀을 사용하는 가장 큰 특징은 실험하는 동안 시스템의 조 성을 일정하게 유지시켜 준다는 것이다. 조성이 알려 진 유체 혼합물을 포함하고 있는 셀의 부피를 변화시 키면서 셀에 설치되어 있는 투시 창을 통하여 셀 안 에서 일어나고 있는 상변화를 관찰함으로써 혼합물의 상평형 거동을 매우 쉽게 측정할 수 있다.

본 연구에서 가변부피 투시 셀 장치를 사용하여 이 온성 액체에 녹는 $\mathrm{CO}_{2}$ 의 용해도를 측정하기 위한 실 험방법은 기포점 (bubble point) 측정 방법이다. 이 방 법은 온도를 일정하게 유지시키면서 조성을 알고 있 는 이온성 액체와 $\mathrm{CO}_{2}$ 혼합물을 가압하여 단일상으로 만든 후 압력을 서서히 감소시키면 기포들이 발생하 기 시작하는 압력에 도달하는데, 이때의 압력을 기포점 압력이라고 한다. 온도와 혼합물의 조성을 변화시키면 서 기포점 압력을 측정하였는데, 그 실험방법을 간략하
게 설명하면 다음과 같다. 먼저 gas-tight syringe를 사용 하여 임의의 양(약 $8 \mathrm{~g})$ 의 이온성 액체 시료를 취한 후 질량을 측정한 후 이를 stirring bar와 함께 가변부피 셀 안으로 넣었다. 다음으로 셀에 피스톤, 오링, 그리고 사 파이어 투시창을 결합한 후 셀을 air bath 내부에 장착 시켰다. 주입된 이온성 액체의 질량은 $\pm 0.1 \mathrm{mg}$ 의 정밀 도를 가지는 정밀저울(AND model HM-30)을 사용하여 측정하였다. 이온성 액체 내부에 있을지 모르는 공기나 불순물 가스를 제거하기 위해 진공펌프를 사용하여 셀 내부를 상온에서 24 시간 정도 진공처리를 하였다. 이 를 통해 셀 내부의 액상은 순수한 이온성 액체가 존재 하도록 하고 기체상은 완전한 진공 상태가 되게 하였다. 이 상태에서 $\mathrm{CO}_{2}$ 기체가 들어가 있는 샘플 실린더를 셀에 연결한 후 $\mathrm{CO}_{2}$ 를 셀 안으로 주입하였다. 정밀 저 울을 사용하여 주입하기 전과 후의 $\mathrm{CO}_{2}$ 샘플 실린더의 무게를 측정하여 주입된 $\mathrm{CO}_{2}$ 의 질량을 결정하였다. 샘 플 실린더의 무게는 $\pm 1 \mathrm{mg}$ 의 정밀도를 가지는 정밀저 울 (Precisa model $1212 \mathrm{M}$ )을 사용하여 측정하였다. $\mathrm{CO}_{2}$ 주입 시에 주입 라인에 남아 있는 $\mathrm{CO}_{2}$ 기체의 손실을 방지하기 위하여, $\mathrm{CO}_{2}$ 기체를 주입한 후 샘플 실린더를 바로 액체 질소로 채워진 Dewer flask 안으로 실린더를 담가 주입 라인에 있는 $\mathrm{CO}_{2}$ 기체를 다시 실린더 안으 로 완전히 회수하였다. 이온성 액체와 $\mathrm{CO}_{2}$ 두 성분들의 질량을 측정할 때의 불확실도는 이온성 액체의 경우는 $0.2 \mathrm{mg}$ 이었으며 $\mathrm{CO}_{2}$ 의 경우는 $2 \mathrm{mg}$ 이었다. 각 성분의 조성(몰분율)에 대한 불확실도 분석은 ISO 가이드라인 에 따라 수행하였다. ${ }^{31}$

시스템의 온도가 원하는 온도에서 일정하게 유지될 때, 시스템의 압력을 변화시키면서 조성이 일정하게 유지되는 이온성 액체와 $\mathrm{CO}_{2}$ 혼합용액의 상변화를 관 찰하였다. 먼저 시스템의 압력을 계속 증가시키면 $\mathrm{CO}_{2}$ 가 이온성 액체에 용해되어 결국 셀 안에 있는 유 체는 단일 균일상이 된다. 실험이 진행되는 동안 교반 기를 사용하여 셀 내부의 용액을 계속적으로 교반시 킨다. 온도가 일정하게 유지되고 혼합물 용액이 단일 상으로 유지되면 압력을 서서히 낮추었다. 압력이 감 소함에 따라 단일상으로부터 아주 조그만 $\mathrm{CO}_{2}$ 기포들 이 나오기 시작하는 압력에 도달하는데, 이때의 압력 이 기포점 압력이다. 몰분율 기준으로 $\mathrm{CO}_{2}$ 의 조성이 높을 때에는 (약 0.74 이상) 기포점 현상이 관찰되는 대신 구름점 (cloud point) 현상이 관찰되었다. 구름점 은 용액이 단일상에서 액-액 상으로 변하는 압력으로 이 압력에 도달하면 용액의 모습이 구름에 둘러싸인 것처럼 뿌옇게 변하게 된다. 본 실험에서 구름점은 셀 
안에서 교반되는 stirring bar가 안보일 때로 정의하였다. 기포점 및 구름점 압력 측정에 대한 불확실도는 0.02 $\mathrm{MPa}$ 이었다. 일관되고 정확한 측정을 재현하기 위하여 모든 측정은 각 온도에서 최소한 두 번 이상 반복하였 다. 온도를 약 $10{ }^{\circ} \mathrm{C}$ 간격으로 증가시키면서 같은 방법 으로 기포점 또는 구름점 압력을 측정하여 주어진 $\mathrm{CO}_{2}$ 조성에서의 압력-온도 $(P-T)$ 선도를 완성하였다.

\section{3. 열역학적 모델링}

이온성 액체와 기체의 혼합물 시스템에서 이온성 액체는 비휘발성이기 때문에 기체상에는 순수 기체만 이 존재한다. 상평형을 위한 조건은 일정한 온도와 압 력에서 기체 성분의 퓨가시티(fugacity)가 두 상에서 모두 같은 값을 가질 때 충족된다.

$$
\mathrm{f}_{1}^{\mathrm{gas}}=\hat{\mathrm{f}}_{1}^{\mathrm{IL}}
$$

여기서 $\mathrm{f}_{1}^{\mathrm{gas}}$ 와 $\hat{\mathrm{f}}_{1}^{\mathrm{IL}}$ 는 각각 기체상과 이온성 액체 상에 서 $\mathrm{CO}_{2}$ (성분 1)의 퓨가시티이다. 온도와 압력에 대한 퓨가시티의 관계식은 상태방정식을 사용하여 표현될 수 있다. 본 연구에서 사용한 열역학 모델은 Peng-Robinson 상태방정식(PR-EoS)이다. PR-EoS는 여러 가지 상태방 정식 중에서 가장 많이 사용되는 상태방정식 중의 하나 로 다음과 같이 표현된다. ${ }^{32}$

$$
\mathrm{P}=\frac{\mathrm{RT}}{\mathrm{V}-\mathrm{b}}-\frac{\mathrm{a}(\mathrm{T})}{\mathrm{V}(\mathrm{V}+\mathrm{b})+\mathrm{b}(\mathrm{V}-\mathrm{b})}
$$

이온성 액체 상 용액에 대한 상태방정식 매개변수 $(a, b)$ 를 계산하기 위해서는 용액에 포함되어 있는 순 수성분들의 상태방정식 매개변수들과 용액의 조성으 로부터 혼합 용액의 매개변수를 계산하는 혼합법칙 (mixing rules)이 필요한데, 다음의 식들을 사용하였다

$$
\begin{aligned}
& a=\sum_{i} \sum_{j} x_{i} x_{j} a_{i j} \\
& a_{i j}=\left(a_{i i} a_{j j}\right)^{1 / 2}\left(1-k_{i j}\right) \\
& b=\sum_{i} \sum_{j} x_{i} x_{j} b_{i j} \\
& b_{i j}=\left(\frac{b_{i}+b_{j}}{2}\right)\left(1-l_{i j}\right)
\end{aligned}
$$

위 식에서 $x_{i}$ 는 혼합물에서 $i$ 성분의 조성(몰분율)이 며, 식 (5)에서 $\mathrm{b}_{\mathrm{ii}}=\mathrm{b}_{\mathrm{i}}, \mathrm{b}_{\mathrm{jj}}=\mathrm{b}_{\mathrm{j}}$, 식 (4)와 (6)에서 $\mathrm{k}_{\mathrm{ij}}$ 와 $l_{\mathrm{ij}}$ 는 이성분 상호작용 매개변수 (binary interaction parameter)이다. 순수 성분 $i$ 에 대한 $\operatorname{EoS}$ 매개변수들 은 다음의 식으로부터 얻어진다.

$$
\begin{aligned}
& \mathrm{a}_{\mathrm{ii}}=\frac{0.457235 \mathrm{R}^{2} \mathrm{~T}_{\mathrm{ci}}^{2}}{\mathrm{P}_{\mathrm{ci}}} \\
& {\left[1+\left(0.37464+1.54226 \mathrm{w}_{\mathrm{i}}-0.26992 \mathrm{w}_{\mathrm{i}}^{2}\right)\left(1-\sqrt{\frac{\mathrm{T}}{\mathrm{T}_{\mathrm{ci}}}}\right)\right]^{2}} \\
& \mathrm{~b}_{\mathrm{i}}=\frac{0.077796 \mathrm{RT}_{\mathrm{ci}}}{\mathrm{P}_{\mathrm{ci}}}
\end{aligned}
$$

기체상과 액체상에서의 $\mathrm{CO}_{2}$ 성분의 퓨가시티는 각 각 다음의 식들로부터 계산된다.

$$
\begin{aligned}
& \operatorname{lnf}_{1}^{\text {gas }}=\ln P+\left(Z_{1}-1\right)-\ln \left(Z_{1}-\frac{b_{1} P}{R T}\right) \\
& -\frac{a_{11}}{2 \sqrt{2} b_{1} R T} \ln \left[\frac{Z_{1}+(\sqrt{2}+1) b_{1} P / R T}{Z_{1}-(\sqrt{2}-1) b_{1} P / R T}\right] \\
& \operatorname{Inf}_{1}^{I L}=\ln \left(x_{1} P\right)+\left(\frac{2}{b} \sum_{j} x_{j} b_{1 j}-1\right)(Z-1)-\ln \left(Z-\frac{b P}{R T}\right) \\
& -\frac{a}{2 \sqrt{2} b R T}\left[\frac{2}{a} \sum_{j} x_{j} a_{1 j}-\left(\frac{2}{b} \sum_{j} x_{j} b_{1 j}-1\right)\right] \\
& {\left[\frac{Z+(\sqrt{2}+1) b T / R T}{Z-(\sqrt{2}+1) b T / R T}\right]}
\end{aligned}
$$

여기에서 $\mathrm{Z}_{1}=\mathrm{PV}_{1}^{\mathrm{gas}} / \mathrm{RT}$ 와 $\mathrm{Z}=\mathrm{PV}^{\mathrm{IL}} / \mathrm{RT}$ 이다. $\mathrm{V}_{1}^{\mathrm{gas}}$ 와 $\mathrm{V}^{\mathrm{IL}}$ 는 각각 기체 상과 이온성 액체 상의 몰부피이다.

PR-EoS 모델을 사용하기 위해서는 각각의 순수 성 분들에 대한 임계성질과 이심인자 (acentric factor)에 대한 값들이 필요하다. 이 값들은 $\mathrm{CO}_{2}$ 에 대해 잘 알 려져 있지만 이온성 액체에 알려져 있지 않다. 그러므 로 PR-EoS 모델을 사용하기 위해서는 먼저 이온성 액체에 대한 임계성질과 이심인자 값들을 추정하여야 한다. 본 연구에서는 이온성 액체에 대한 임계온도 $\left(T_{c}\right)$ 와 임계압력 $\left(P_{c}\right)$ 과 이심인자 $(\omega)$ 를 추정하기 위하여 그룹기여 방법에 기초한 Lydersen, Joback, Reid의 방 법을 통합하고 수정한 방법으로서 Valderrama 등 ${ }^{33}$ 이 이온성 액체의 임계값들과 이심인자 등을 계산할 때 사용하도록 제시한 수정된 Lydersen-Joback-Reid 방법

Table 2. Critical properties and acentric factor of $\mathrm{CO}_{2}$ and ionic liquid

\begin{tabular}{cccc}
\hline \hline \multirow{2}{*}{ Substance } & Critical & Critical & Acentric \\
& temperature, & pressure, & factor, \\
& $T_{c}(\mathrm{~K})$ & $P_{c}(\mathrm{MPa})$ & $\omega$ \\
\hline $\mathrm{CO}_{2}$ & 304.2 & 7.38 & 0.224 \\
{$\left[\right.$ bmpip] $\left[\mathrm{Tf}_{2} \mathrm{~N}\right]$} & 1233.4 & 2.34 & 0.347 \\
\hline
\end{tabular}


을 이용하였다. 이 방법을 사용하여 구한 이온성 액체 의 임계성질 및 이심인자 값들을 $\mathrm{CO}_{2}$ 에 대한 값들과 함께 Table 2에 나타내었다.
주어진 온도에서 $\mathrm{CO}_{2}+$ 이온성 액체 시스템에 대한 상평형 계산은 여러 가지 $\mathrm{CO}_{2}$ 조성에서 식 (1)의 상평 형 관계식과 식 (2)의 PR-EoS를 만족시키는 평형 압력

Table 3. Experimental bubble or cloud point data for various mole fractions of $\mathrm{CO}_{2}$ in the $\mathrm{CO}_{2}+\left[\right.$ bmpip][Tf $\left.\mathrm{T}_{2} \mathrm{~N}\right]$ system

\begin{tabular}{|c|c|c|c|c|c|}
\hline $\begin{array}{l}\text { Mole fraction } \\
\text { of } \mathrm{CO}_{2}, x_{1}\end{array}$ & $\begin{array}{l}\text { Uncertainty } \\
\text { in } x_{1}, U\left(x_{1}\right)\end{array}$ & $\begin{array}{c}\text { Molality, } m_{1} \\
\text { (mol CO} / 2 \text { of ionic liquid) }\end{array}$ & $T(\mathrm{~K})$ & $P(\mathrm{MPa})$ & $\begin{array}{c}\text { Phase behavior } \\
\text { observed }\end{array}$ \\
\hline \multirow{5}{*}{0.1059} & \multirow{5}{*}{0.0022} & \multirow{5}{*}{0.2714} & 303.5 & 0.18 & $b^{*}$ \\
\hline & & & 313.3 & 0.27 & $\mathrm{~b}$ \\
\hline & & & 322.4 & 0.38 & $\mathrm{~b}$ \\
\hline & & & 333.0 & 0.48 & $\mathrm{~b}$ \\
\hline & & & 343.9 & 0.61 & $\mathrm{~b}$ \\
\hline \multirow{5}{*}{0.1875} & \multirow{5}{*}{0.0041} & \multirow{5}{*}{0.5288} & 302.9 & 0.29 & $\mathrm{~b}$ \\
\hline & & & 313.6 & 0.38 & $\mathrm{~b}$ \\
\hline & & & 323.0 & 0.51 & $\mathrm{~b}$ \\
\hline & & & 333.5 & 0.72 & $\mathrm{~b}$ \\
\hline & & & 343.0 & 0.92 & $\mathrm{~b}$ \\
\hline \multirow{5}{*}{0.2724} & \multirow{5}{*}{0.0056} & \multirow{5}{*}{0.8580} & 302.9 & 0.93 & $\mathrm{~b}$ \\
\hline & & & 313.3 & 1.22 & $\mathrm{~b}$ \\
\hline & & & 322.7 & 1.47 & $\mathrm{~b}$ \\
\hline & & & 333.4 & 1.79 & $\mathrm{~b}$ \\
\hline & & & 343.7 & 2.12 & $\mathrm{~b}$ \\
\hline \multirow{5}{*}{0.3158} & \multirow{5}{*}{0.0071} & \multirow{5}{*}{1.0575} & 302.7 & 1.32 & $\mathrm{~b}$ \\
\hline & & & 312.4 & 1.62 & $\mathrm{~b}$ \\
\hline & & & 322.7 & 1.99 & $\mathrm{~b}$ \\
\hline & & & 332.9 & 2.38 & $\mathrm{~b}$ \\
\hline & & & 343.0 & 2.80 & $\mathrm{~b}$ \\
\hline \multirow{5}{*}{0.3743} & \multirow{5}{*}{0.0082} & \multirow{5}{*}{1.3708} & 302.9 & 1.67 & $\mathrm{~b}$ \\
\hline & & & 313.5 & 2.07 & $\mathrm{~b}$ \\
\hline & & & 322.4 & 2.46 & $\mathrm{~b}$ \\
\hline & & & 332.4 & 2.93 & $\mathrm{~b}$ \\
\hline & & & 343.4 & 3.48 & $\mathrm{~b}$ \\
\hline \multirow{5}{*}{0.4163} & \multirow{5}{*}{0.0093} & \multirow{5}{*}{1.6342} & 303.1 & 1.98 & $\mathrm{~b}$ \\
\hline & & & 313.3 & 2.46 & $\mathrm{~b}$ \\
\hline & & & 323.2 & 2.94 & $\mathrm{~b}$ \\
\hline & & & 333.1 & 3.48 & $\mathrm{~b}$ \\
\hline & & & 343.9 & 4.05 & $\mathrm{~b}$ \\
\hline \multirow{5}{*}{0.4564} & \multirow{5}{*}{0.0103} & \multirow{5}{*}{1.9235} & 302.7 & 2.17 & $\mathrm{~b}$ \\
\hline & & & 312.8 & 2.70 & $\mathrm{~b}$ \\
\hline & & & 322.9 & 3.29 & $\mathrm{~b}$ \\
\hline & & & 332.7 & 3.89 & $\mathrm{~b}$ \\
\hline & & & 343.0 & 4.59 & $\mathrm{~b}$ \\
\hline \multirow{5}{*}{0.4886} & \multirow{5}{*}{0.0112} & & 303.1 & 2.56 & $\mathrm{~b}$ \\
\hline & & & 313.5 & 3.15 & $\mathrm{~b}$ \\
\hline & & 2.1889 & 323.2 & 3.74 & $\mathrm{~b}$ \\
\hline & & & 332.8 & 4.47 & $\mathrm{~b}$ \\
\hline & & & 343.0 & 5.25 & $\mathrm{~b}$ \\
\hline & & & 303.1 & 2.98 & $b$ \\
\hline & & & 312.8 & 3.64 & $\mathrm{~b}$ \\
\hline 0.5453 & 0.0115 & 2.7476 & 322.9 & 4.48 & $\mathrm{~b}$ \\
\hline & & & 332.8 & 5.38 & $\mathrm{~b}$ \\
\hline & & & 342.6 & 6.22 & $\mathrm{~b}$ \\
\hline
\end{tabular}


Table 3. (Continued)

\begin{tabular}{|c|c|c|c|c|c|}
\hline $\begin{array}{l}\text { Mole fraction } \\
\text { of } \mathrm{CO}_{2}, x_{1}\end{array}$ & $\begin{array}{l}\text { Uncertainty } \\
\text { in } x_{1}, U\left(x_{1}\right)\end{array}$ & $\begin{array}{c}\text { Molality, } m_{1} \\
\text { (mol CO} / \mathrm{kg} \text { of ionic liquid) }\end{array}$ & $T(\mathrm{~K})$ & $P(\mathrm{MPa})$ & $\begin{array}{c}\text { Phase behavior } \\
\text { observed }\end{array}$ \\
\hline \multirow{5}{*}{0.5870} & \multirow{5}{*}{0.0118} & \multirow{5}{*}{3.2564} & 303.0 & 3.67 & $\mathrm{~b}$ \\
\hline & & & 313.4 & 4.56 & $\mathrm{~b}$ \\
\hline & & & 322.3 & 5.45 & $\mathrm{~b}$ \\
\hline & & & 333.1 & 6.57 & $\mathrm{~b}$ \\
\hline & & & 343.3 & 7.72 & $\mathrm{~b}$ \\
\hline \multirow{5}{*}{0.6308} & \multirow{5}{*}{0.0118} & \multirow{5}{*}{3.9149} & 302.8 & 4.23 & $\mathrm{~b}$ \\
\hline & & & 313.0 & 5.27 & $\mathrm{~b}$ \\
\hline & & & 322.5 & 6.34 & $\mathrm{~b}$ \\
\hline & & & 332.9 & 7.69 & $b$ \\
\hline & & & 343.1 & 9.14 & $\mathrm{~b}$ \\
\hline \multirow{5}{*}{0.6714} & \multirow{5}{*}{0.0117} & \multirow{5}{*}{4.6811} & 303.8 & 5.15 & $\mathrm{~b}$ \\
\hline & & & 313.0 & 6.36 & $\mathrm{~b}$ \\
\hline & & & 322.4 & 7.73 & $\mathrm{~b}$ \\
\hline & & & 333.4 & 9.59 & $\mathrm{~b}$ \\
\hline & & & 343.3 & 11.55 & $\mathrm{~b}$ \\
\hline \multirow{5}{*}{0.7116} & \multirow{5}{*}{0.0113} & \multirow{5}{*}{5.6528} & 304.2 & 6.35 & $\mathrm{~b}$ \\
\hline & & & 313.9 & 7.99 & $\mathrm{~b}$ \\
\hline & & & 322.3 & 9.99 & $\mathrm{~b}$ \\
\hline & & & 332.7 & 13.07 & $\mathrm{~b}$ \\
\hline & & & 343.0 & 16.24 & $\mathrm{~b}$ \\
\hline \multirow{5}{*}{0.7438} & \multirow{5}{*}{0.0110} & \multirow{5}{*}{6.6505} & 303.5 & 7.30 & $\mathrm{~b}$ \\
\hline & & & 313.7 & 10.53 & $\mathrm{c}^{* *}$ \\
\hline & & & 322.8 & 14.35 & $\mathrm{c}$ \\
\hline & & & 332.2 & 18.35 & $\mathrm{c}$ \\
\hline & & & 342.5 & 22.10 & $\mathrm{c}$ \\
\hline \multirow{5}{*}{0.7685} & \multirow{5}{*}{0.0108} & \multirow{5}{*}{7.6082} & 302.9 & 10.60 & $\mathrm{c}$ \\
\hline & & & 312.7 & 15.80 & $\mathrm{c}$ \\
\hline & & & 323.2 & 20.99 & c \\
\hline & & & 333.5 & 24.95 & $\mathrm{c}$ \\
\hline & & & 343.0 & 28.90 & $\mathrm{c}$ \\
\hline
\end{tabular}

*Bubble point behavior observed.

**Cloud point behavior observed.

을 계산하여 $\mathrm{P}-\mathrm{x}_{1}$ 그래프를 완성하는 것이다. 이를 위 해서는 먼저 식 (4)와 식 (6)에 주어진 이성분 상호작 용 매개변수, $\mathrm{k}_{\mathrm{ij}}$ 와 $l_{\mathrm{ij}}$ 값을 결정하여야 한다. 본 연구에서 는 IMSL/Math library의 UNLSF subroutine (LevenbergMarquardt algorithm을 이용한 비선형 최소자승 문제 풀이법)을 사용하여 실험 데이터를 PR-EoS 모델에 상 관시킴으로서 $\mathrm{k}_{\mathrm{ij}}$ 와 $l_{\mathrm{ij}}$ 의 최적값을 구하였다. ${ }^{34,35}$ 기포 점 실험 데이터를 $\mathrm{PR}-\mathrm{EoS}$ 에 대입시키고 다음의 목적 함수를 최소화하는 $\mathrm{k}_{\mathrm{ij}}$ 와 $l_{\mathrm{ij}}$ 의 최적값을 얻었다.

$$
\mathrm{F}=\sum_{\mathrm{m}=1}^{\mathrm{N}} \frac{\left|\mathrm{P}_{\mathrm{m}}^{\mathrm{calc}}-\mathrm{P}_{\mathrm{m}}^{\exp }\right|}{\mathrm{P}_{\mathrm{m}}^{\exp }}
$$

여기서, $\mathrm{P}_{\mathrm{m}}^{\exp }$ 는 데이터 포인트 $m$ 에 대한 실험값이고
$\mathrm{P}_{\mathrm{m}}^{\mathrm{calc}}$ 는 같은 데이터 포인트에 대하여 PR-EoS에 의한 계산된 값이며, $N$ 은 데이터 포인트의 개수다. 주어진 온도에서 $\mathrm{k}_{\mathrm{ij}}$ 와 $l_{\mathrm{ij}}$ 의 최적값을 사용하여 액상 조성 $\left(\mathrm{x}_{1}\right)$ 을 0 부터 1 까지 작은 간격으로 변화시키면서 식 (1)을 만족시키는 압력의 계산을 반복함으로서 $\mathrm{P}-\mathrm{x}_{1}$ 선도를 완성하였다. 이 계산을 위해서는 IMSL/Math library의 NEQNF subroutine (modified Powell hybrid algorithm을 이용한 비선형 연립방정식 풀이법)을 사용하였다. ${ }^{34,35}$

\section{4. 결과 및 고찰}

\section{1. [bmpip][Tf $2 \mathrm{~N}]$ 에 대한 $\mathrm{CO}_{2}$ 의 용해도}

본 연구에서 수행한 이온성 액체 [bmpip] $\left[\mathrm{Tf}_{2} \mathrm{~N}\right]$ 와

Vol. 27, No. 2, 2014 
$\mathrm{CO}_{2}$ 의 이성분 혼합물에 대한 상거동 실험 결과를 Table 3에 나타내었다. 약 $303 \mathrm{~K}$ 부터 약 $343 \mathrm{~K}$ 까지의 온도 범위에서 $\mathrm{CO}_{2}$ 의 조성을 변화시켜가면서 $\mathrm{CO}_{2}$ 와 이온성 액체 혼합물에 대해 측정한 기포점 또는 구름 점에서의 압력을 수록하였으며, 각각의 데이터 포인트 에 대하여 관찰된 상변화의 종류도 역시 표시하였다. Table 3 에 수록된 $\mathrm{CO}_{2}$ 의 몰분율 (mole fraction) $x_{1}$ 이 그 물분율에 대응하는 온도와 압력에서의 이온성 액 체에 대한 $\mathrm{CO}_{2}$ 의 용해도이다. 또한 이온성 액체에 대 한 $\mathrm{CO}_{2}$ 의 용해도를 몰랄농도 (molality), 즉 이온성 액 체 단위 $\mathrm{kg}$ 당 $\mathrm{CO}_{2}$ 의 몰수를 기준으로도 나타내었다. Table 3에는 $\mathrm{CO}_{2}$ 몰분율 측정에서의 불확실도를 각각 의 포인트에 대해 수록하였다. 전체 데이터를 고려할 때 몰분율에 대한 평균 불확실도는 0.0092 로 추산되 었다. 한편 Table 3 을 보면 구름점 현상은 기포점 현 상이 나타날 때보다 더 높은 $\mathrm{CO}_{2}$ 몰분율을 가질 때 (약 0.74 이상에서) 나타난다는 것을 알 수 있다.

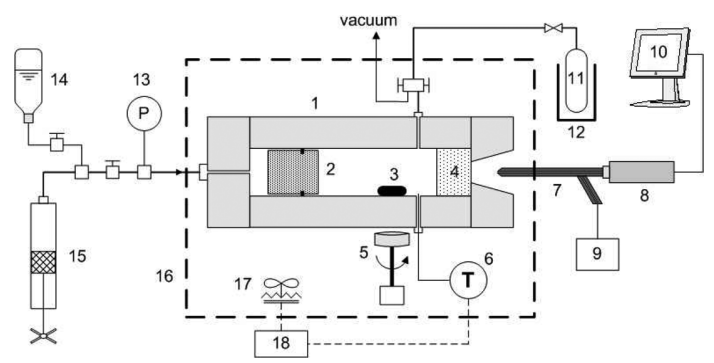

Fig. 2. A schematic diagram of the experimental apparatus.
Table 3의 실험 데이터를 P-T 선도로 Fig. 3에 나타 내었다. Fig. 3 을 보면 알 수 있듯이, $\mathrm{CO}_{2}$ 몰분율이 일 정할 때 온도가 증가함에 따라 상평형 압력이 증가하 였다. 또한 온도가 일정할 때는 $\mathrm{CO}_{2}$ 몰분율이 증가함 에 따라 상평형 압력이 급격하게 증가하였다. 일반적 으로 이온성 액체에 대한 $\mathrm{CO}_{2}$ 를 비롯한 기체의 용해 도는 압력의 증가에 따라 증가하며, 온도의 증가에 따 라 감소하는 경향을 보인다. 특히 이러한 경향은 물리 적 흡수에 의존하는 대부분의 이온성 액체에 공통적 으로 적용되며, $\mathrm{CO}_{2}$ 흡수능이 큰 화학적 흡수의 경우

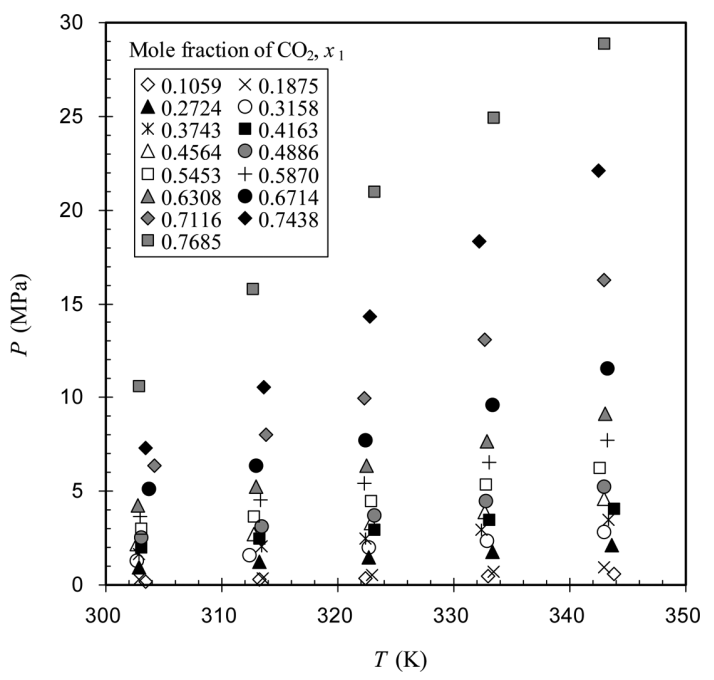

Fig. 3. P-T isopleths of the $\mathrm{CO}_{2}+[$ bmpip $]\left[\mathrm{Tf}_{2} \mathrm{~N}\right]$ mixtures at different mole fractions of $\mathrm{CO}_{2}\left(x_{1}\right)$

Table 4. Interpolated isothermal solubility data for $\mathrm{CO}_{2}$ in $\left[\right.$ bmpip] $\left.\mathrm{Tf}_{2} \mathrm{~N}\right]$

\begin{tabular}{|c|c|c|c|c|c|c|}
\hline \multirow{2}{*}{$\begin{array}{l}\text { Mole fraction } \\
\text { of } \mathrm{CO}_{2}, x_{1}\end{array}$} & \multirow{2}{*}{$\begin{array}{c}\text { Molality, } m_{1} \\
\text { (mol CO} / 2 / k g \text { ionic liquid) }\end{array}$} & \multicolumn{5}{|c|}{$\mathrm{P}(\mathrm{MPa})$ at following temperature } \\
\hline & & $303.2 \mathrm{~K}$ & $313.2 \mathrm{~K}$ & $323.2 \mathrm{~K}$ & $333.2 \mathrm{~K}$ & $343.2 \mathrm{~K}$ \\
\hline 0.1059 & 0.2714 & 0.18 & 0.28 & 0.38 & 0.49 & 0.60 \\
\hline 0.1875 & 0.5288 & 0.29 & 0.38 & 0.52 & 0.70 & 0.93 \\
\hline 0.2724 & 0.8580 & 0.94 & 1.21 & 1.49 & 1.79 & 2.10 \\
\hline 0.3158 & 1.0575 & 1.33 & 1.65 & 2.01 & 2.39 & 2.81 \\
\hline 0.3743 & 1.3708 & 1.68 & 2.07 & 2.49 & 2.96 & 3.47 \\
\hline 0.4163 & 1.6342 & 1.98 & 2.45 & 2.95 & 3.47 & 4.02 \\
\hline 0.4564 & 1.9235 & 2.20 & 2.72 & 3.30 & 3.93 & 4.60 \\
\hline 0.4886 & 2.1889 & 2.57 & 3.12 & 3.76 & 4.48 & 5.27 \\
\hline 0.5453 & 2.7476 & 2.97 & 3.71 & 4.51 & 5.37 & 6.30 \\
\hline 0.5870 & 3.2564 & 3.68 & 4.56 & 5.53 & 6.58 & 7.71 \\
\hline 0.6308 & 3.9149 & 4.27 & 5.28 & 6.44 & 7.73 & 9.16 \\
\hline 0.6714 & 4.6811 & 5.09 & 6.36 & 7.86 & 9.58 & 11.52 \\
\hline 0.7116 & 5.6528 & 6.13 & 7.95 & 10.26 & 13.07 & 16.38 \\
\hline 0.7438 & 6.6505 & 7.23 & 10.36 & 14.50 & 18.77 & 22.30 \\
\hline 0.7685 & 7.6082 & 10.80 & 16.05 & 20.81 & 25.08 & 28.87 \\
\hline
\end{tabular}


에도 일정량의 $\mathrm{CO}_{2}$ 흡수 후에는 물리적 흡수에 의존 하는 경향을 보인다. ${ }^{9-20}$ 이온성 액체로 [bmpip] [Tf $\left.{ }_{2} \mathrm{~N}\right]$ 를 사용한 본 연구에서도 같은 경향을 확인할 수 있 었다.

이온성 액체에 대한 $\mathrm{CO}_{2}$ 의 용해도를 온도와 압력 의 함수로 더 명확하게 나타내기 위하여 다음의 과정 을 수행하였다. 먼저 Fig. 3의 P-T 선도에 보인 각각 의 $\mathrm{CO}_{2}$ 몰분율에 대하여 압력을 온도의 함수로 표현한 추세선 식(2 차 다항식)으로 나타내고, 그 추세선 식을 사용하여 다섯 개의 온도 $(303.2 \mathrm{~K}, 313.2 \mathrm{~K}, 323.2 \mathrm{~K}$, $333.2 \mathrm{~K}, 343.2 \mathrm{~K})$ 를 대입하여 각 온도에 대한 압력을
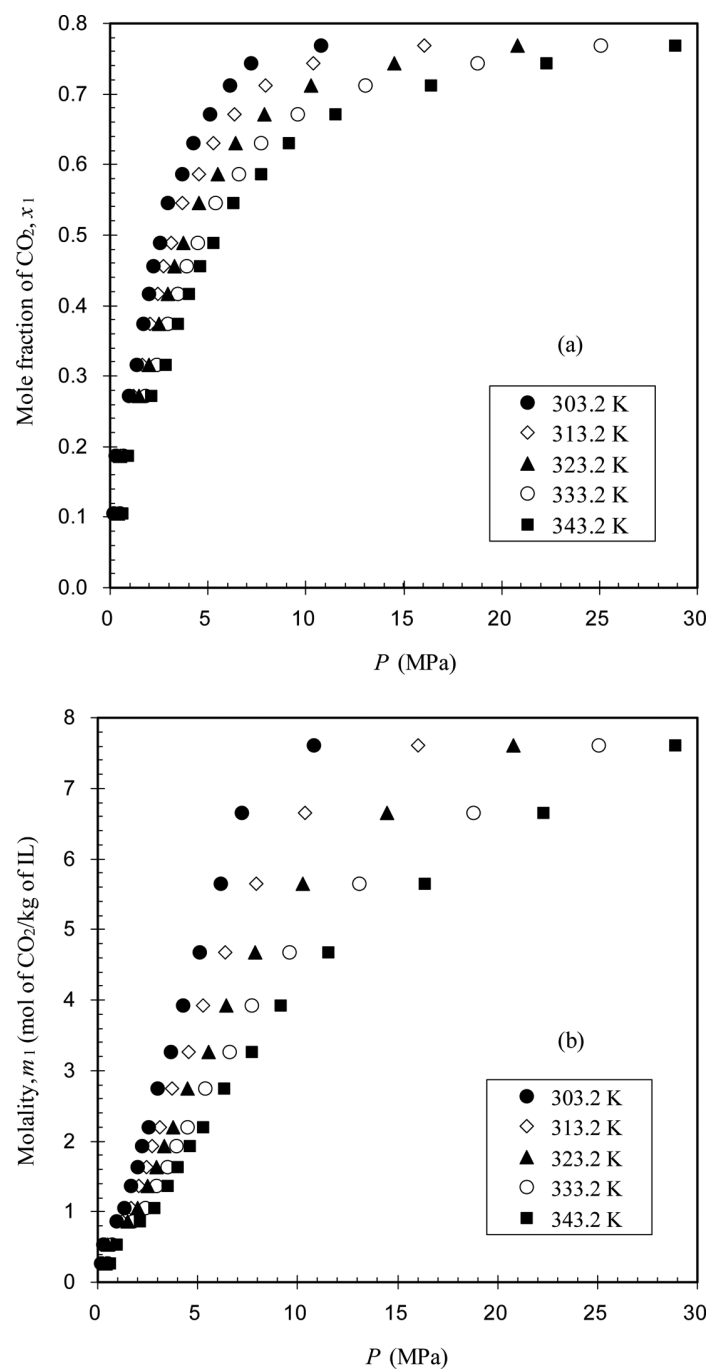

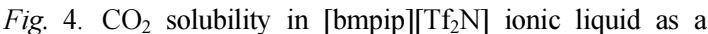
function of pressure at different temperatures: (a) in mole fraction; (b) in molality.
구하였다. 그 다음, 각각의 온도에 대하여 $\mathrm{CO}_{2}$ 의 용해 도를 압력의 함수로 정리하여 선도 및 표로 나타내었 다. Fig. 4는 $303.2 \mathrm{~K}$ 부터 $343.2 \mathrm{~K}$ 까지의 각각의 온도 에 대한 $\mathrm{CO}_{2}$ 의 용해도를 [bmpip][Tf $\left.2 \mathrm{~N}\right]$ 에 대한 $\mathrm{CO}_{2}$ 의 용해도 선도를 보여주고 있으며, 이를 Table 4에 수록 하였다. 본 연구에서는 이온성 액체에 대한 $\mathrm{CO}_{2}$ 의 용 해도를 두 가지 단위로 나타내었다. Fig. 4(a)에서는 $\mathrm{CO}_{2}$ 의 용해도를 몰분율로 나타내었으며, 반면에 Fig. 4(b)에서는 $\mathrm{CO}_{2}$ 의 용해도를 몰랄농도로 나타내었다.

Fig. 4(a)를 보면 알 수 있듯이, 주어진 온도에서 [bmpip] [ $\left.\mathrm{Tf}_{2} \mathrm{~N}\right]$ 에 용해되는 $\mathrm{CO}_{2}$ 의 몰분율은 압력이 증가함에 따라 급격히 증가하다가 약 $10 \mathrm{MPa}$ 의 압력 부터는 용해도의 증가율이 급격히 감소하였다. 온도에 따라 다소 차이는 있지만 압력을 더 증가시켜도 $\mathrm{CO}_{2}$ 의 용해도는 몰분율을 기준으로 0.75 내지는 0.8 에서 거의 포화 상태에 도달한다는 것을 알 수 있었다. 또 한 같은 압력에서 비교할 때 온도가 낮을수록 $\mathrm{CO}_{2}$ 의 용해도가 높아진다는 것을 알 수 있었다. 이러한 용해 도 거동 특성은 이온성 액체에 대한 $\mathrm{CO}_{2}$ 의 용해도가 온도와 압력에 따라 변화할 때 보여주는 전형적인 특 성과 일치한다. 본 연구의 대상 물질인 [bmpip][Tf $\left.{ }_{2} \mathrm{~N}\right]$ 이온성 액체의 경우 $\mathrm{CO}_{2}$ 에 대하여 기본적으로 물리흡 수 현상을 보이는 물질이기 때문에 어떤 압력 이상에 서는 압력을 증가시켜도 이온성 액체에 흡수된 $\mathrm{CO}_{2}$ 의 몰분율은 크게 변하지 않았으며 이는 물리흡수의 한 계점으로 보인다. 만일 화학적인 흡수가 가능한 이온 성 액체라면 압력의 변화에 따른 $\mathrm{CO}_{2}$ 용해도의 변화 양상도 분명 다르게 나타날 것으로 추정된다.

Fig. 4(b)는 다섯 가지의 온도에 대하여 일정한 온 도에서 압력의 변화에 따른 $\mathrm{CO}_{2}$ 의 용해도를 몰랄농도 기준으로 나타낸 것이다. 이 그림에서 볼 수 있듯이 온도별로 약간의 차이는 있지만 $7 \mathrm{MPa}$ 내지는 10 $\mathrm{MPa}$ 까지의 낮은 압력 범위에서는 $\mathrm{CO}_{2}$ 의 몰랄 농도가 압력 변화에 따라 선형적으로 증가하였으며, 더 높은 압력 범위에서는 압력 변화에 따른 몰랄 농도의 증가 율이 점진적으로 감소하였다. 또한 $\mathrm{CO}_{2}$ 의 용해도를 몰분율로 나타내었을 때와는 달리 $\mathrm{CO}_{2}$ 의 용해도를 몰 랄농도로 표시하였을 때는 온도에 따른 $\mathrm{CO}_{2}$ 의 용해도 의 차이가 뚜렷하였으며, 그 차이는 높은 압력의 영역 에서 더 뚜렷하였다.

\section{2. $\mathrm{CO}_{2}$ 용해도의 비교}

Fig. 5는 [bmpip][Tf $\left.\mathrm{f}_{2} \mathrm{~N}\right]$ 와 같은 음이온을 가지면서 imidazolium 계열의 양이온을 갖는 이온성 액체인 1- 

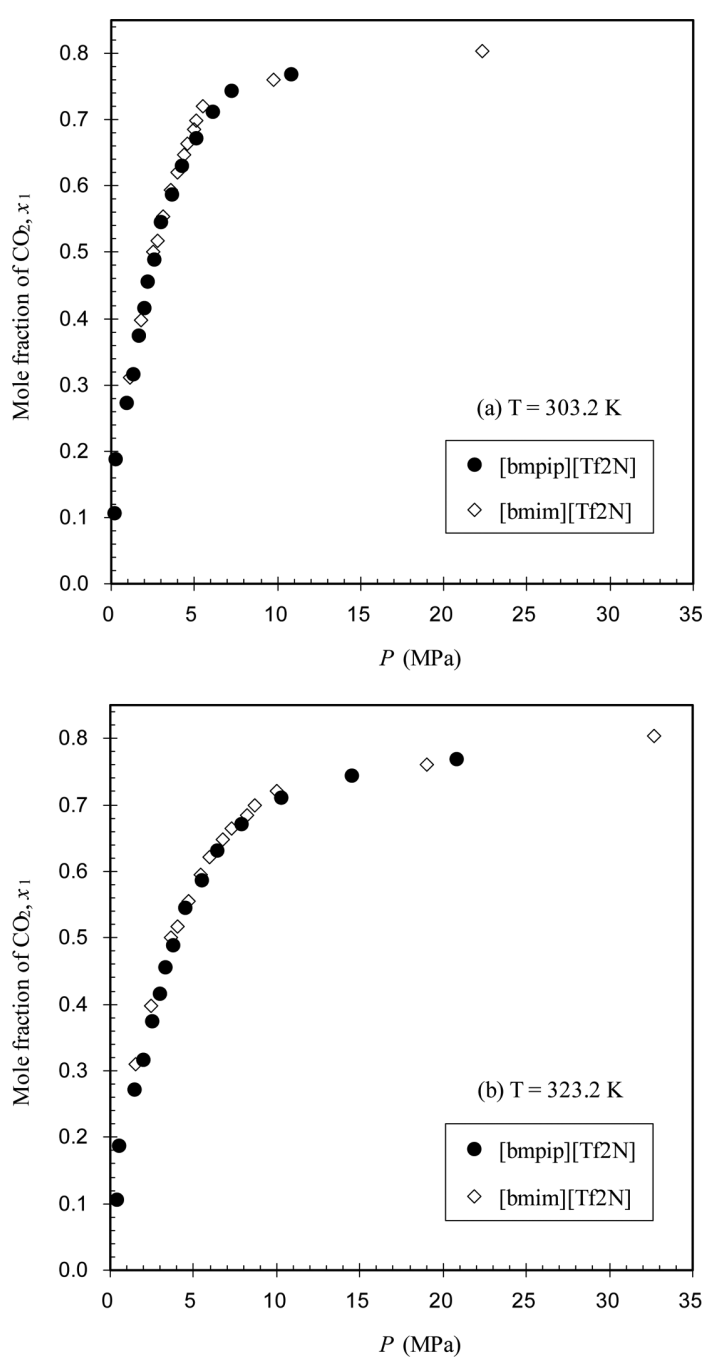

Fig. 5. Comparison of $\mathrm{CO}_{2}$ solubilities in mole fraction for the $\left[\mathrm{Tf}_{2} \mathrm{~N}\right]$ anions-based ionic liquids with different cations: (a) $303.2 \mathrm{~K}$; (b) $323.2 \mathrm{~K}$. The data for [bmim] $\left[\mathrm{Tf}_{2} \mathrm{~N}\right]$ are from reference 16 .

butyl-3-methylimidazoilum bis(trifluoromethylsulfonyl) imide ([bmim] $\left.\left[\mathrm{Tf}_{2} \mathrm{~N}\right]\right)$ 의 $\mathrm{CO}_{2}$ 용해도를 [bmpip][ $\left.\mathrm{Tf}_{2} \mathrm{~N}\right]$ 의 $\mathrm{CO}_{2}$ 용해도와 비교한 것이다. 따라서 이 그림은 $303.2 \mathrm{~K}$ 와 $323.2 \mathrm{~K}$ 의 두 온도에 대하여 이온성 액체 가 갖는 양이온의 구조가 $\mathrm{CO}_{2}$ 용해도에 어떤 영향을 미치는지를 보여주는 것이다. [bmim] $\left[\mathrm{Tf}_{2} \mathrm{~N}\right]$ 의 경우 본 연구실을 포함한 전 세계의 많은 연구실에서 다양한 실험 방법으로 넓은 온도와 압력 범위에 걸쳐 500 포 인트 이상의 $\mathrm{CO}_{2}$ 용해도 데이터를 발표한 바 있으며, ${ }^{21}$ $\mathrm{CO}_{2}$ 용해도 연구 분야에서 지금까지 가장 많이 연구
대상이 된 이온성 액체 중의 하나이다. 반면에 [bmpip] $\left[\mathrm{Tf}_{2} \mathrm{~N}\right]$ 에 대해서는 $\mathrm{CO}_{2}$ 용해도 데이터가 다른 연구자 들에 의해 발표되지 않은 실정이다. 또한 서론에서 이 미 언급하였듯이 imidazolium 계열의 양이온과 [ $\left.\mathrm{Tf}_{2} \mathrm{~N}\right]$ 음이온을 갖는 이온성 액체가 가장 높은 $\mathrm{CO}_{2}$ 용해도 를 보여주는 것으로 알려졌다. 따라서 본 연구를 통해 얻은 [bmpip][Tf $\left.{ }_{2} \mathrm{~N}\right]$ 에 대한 $\mathrm{CO}_{2}$ 용해도 데이터를 본 연구실에서 전에 이미 발표한 ${ }^{16}[\mathrm{bmim}]\left[\mathrm{Tf}_{2} \mathrm{~N}\right]$ 에 대한 데이터와 비교하였다. [bmpip] 양이온의 piperidinium 에 붙어 있는 alkyl chain (1-butyl-3-methyl)의 길이와 [bmim] 양이온의 imidazolium에 붙어 있는 alkyl chain 의 길이는 똑같다는 것에 주목할 필요가 있다.

Fig. 5에서 볼 수 있듯이, $303.2 \mathrm{~K}$ 와 $323.2 \mathrm{~K}$ 의 두 온도 모두에 대하여 [bmpip][Tf $\left.\mathrm{T}_{2} \mathrm{~N}\right]$ 와 [bmim] $\left[\mathrm{Tf}_{2} \mathrm{~N}\right]$ 가 가지는 $\mathrm{CO}_{2}$ 용해도는 저압부터 고압까지의 범위에서 압력에 관계없이 그래프 상으로는 거의 유사한 것으 로 관찰되었다. [bmpip][Tf $\left.\mathrm{T}_{2} \mathrm{~N}\right]$ 와 $[\mathrm{bmim}]\left[\mathrm{Tf}_{2} \mathrm{~N}\right]$ 가 보이 는 $\mathrm{CO}_{2}$ 용해도 결과를 보다 면밀하게 비교하기 위하 여 서론에서 언급된 연소 전 $\mathrm{CO}_{2}$ 포집 공정의 압력 조건(2 6 MPa)에서 두 이온성 액체의 $\mathrm{CO}_{2}$ 용해도를 구하였다. 본 연구에서는 Fig. 5의 데이터를 압력에 대한 다항식으로 맞춰 추세선 식을 구한 후, 압력을 5 $\mathrm{MPa}$ 로 설정하여 이 압력에서의 두 이온성 액체에 대 한 $\mathrm{CO}_{2}$ 용해도를 추산하였으며, 그 결과를 Table 5에 나타내었다. Table 5에서 알 수 있듯이, 두 온도 모두 에 대하여 몰분율 기준으로 [bmpip][Tf $\left.\mathrm{T}_{2} \mathrm{~N}\right]$ 에 대한 $\mathrm{CO}_{2}$ 의 용해도는 $[\mathrm{bmim}]\left[\mathrm{Tf}_{2} \mathrm{~N}\right]$ 에 대한 $\mathrm{CO}_{2}$ 의 용해도 와 거의 같았다. 또한 몰랄농도 기준으로는 [bmim] $\left[\mathrm{Tf}_{2} \mathrm{~N}\right]$ 에 대한 $\mathrm{CO}_{2}$ 의 용해도가 약간 컸다. 이는 Table 5 에 표시하였듯이 [bmpip][Tf $\left.{ }_{2} \mathrm{~N}\right]$ 의 분자량이 [bmim] $\left[\mathrm{Tf}_{2} \mathrm{~N}\right]$ 의 분자량보다 약간 더 크기 때문이다. Table 5 에 명시된 두 온도 외의 다른 온도에서도 그 경향은 같았다. 결론적으로 본 연구를 통해 얻은 [bmpip] $\left[\mathrm{Tf}_{2} \mathrm{~N}\right]$ 에 대한 $\mathrm{CO}_{2}$ 의 용해도는 지금까지 가장 많이 연구가 수행된 [bmim] $\left[\mathrm{Tf}_{2} \mathrm{~N}\right]$ 에 대한 $\mathrm{CO}_{2}$ 의 용해도와 거의 차이가 없었으며, 동일한 음이온 $\left(\left[\mathrm{Tf}_{2} \mathrm{~N}\right]\right)$ 을 가지 며 양이온에 붙어 있는 side chain인 alkyl chain의 길이 가 같은 이 두 종류의 이온성 액체의 경우 piperidinium 양이온과 imidazolium 양이온은 거의 같은 $\mathrm{CO}_{2}$ 용해 도 또는 흡수능을 보여주었다. 이는 [bmpip][Tf $\left.{ }_{2} \mathrm{~N}\right]$ 와 $[\mathrm{bmim}]\left[\mathrm{Tf}_{2} \mathrm{~N}\right]$ 모두 양이온에 붙어 있는 side chain의 길이가 같기 때문에 두 이온성 액체가 가지고 있는 자유 부피(free volume)가 거의 같기 때문인 것으로 판단된다. 또한 두 이온성 액체의 양이온과 $\mathrm{CO}_{2}$ 와의 
결합력도 거의 같기 때문인 것으로 판단된다. 한편 두 이온성 액체가 가지고 있는 음이온인 [ $\left[\mathrm{Tf}_{2} \mathrm{~N}\right]$ 의 경우, 음이온에 존재하는 fluoroalkyl 그룹 $\left(-\mathrm{CF}_{3}\right)$ 은 $\mathrm{CO}_{2}$ 와 매우 높은 결합력을 가지는 것으로 알려져 있다. 따라 서 [bmpip][Tf $\left.{ }_{2} \mathrm{~N}\right]$ 와 $[\mathrm{bmim}]\left[\mathrm{Tf}_{2} \mathrm{~N}\right]$ 에 대해서는 음이온 이 $\mathrm{CO}_{2}$ 용해도에 훨씬 더 우세한 영향을 주기 때문에 양이온의 종류에 의해 크게 영향을 받지 않고 $\mathrm{CO}_{2}$ 용 해도가 거의 유사한 것으로 사료된다.

\section{3. 열역학적 모델링 결과}

험을 통해 얻은 $\mathrm{CO}_{2}+[\mathrm{bmpip}]\left[\mathrm{Tf}_{2} \mathrm{~N}\right]$ 이온성 액체 혼합물의 상평형 데이터를 대상으로 Peng-Robinson 상태방정식을 사용하여 3 장에 기술한 방법으로 모델 링 연구를 수행하였다. Table 4에 보인 P-T 실험 데이 터를 상태방정식에 상관시켜 다섯 개의 온도 각각에 대하여 혼합법칙(식 4 와 식 6)에 포함되어 있는 2 개 의 이성분 상호작용 매개변수, 즉 $\mathrm{k}_{\mathrm{ij}}$ 와 $l_{\mathrm{ij}}$ 의 최적값을 구하였으며, 그 결과를 Table 5에 나타내었다. Table 5 에 주어진 이성분 상호작용 매개변수의 온도 의존성 을 관찰하기 위하여 각각의 매개변수 값들을 다항식 을 사용하여 온도의 함수로 상관시켰으며, 그 결과는 다음과 같다.

$$
\begin{aligned}
& \mathrm{k}_{\mathrm{ij}}=-0.21509+0.57224\left(\frac{\mathrm{T}}{\mathrm{T}_{0}}\right)-0.28489\left(\frac{\mathrm{T}}{\mathrm{T}_{0}}\right)^{2} ; \mathrm{R}^{2}=0.998 \\
& l_{\mathrm{ij}}=0.21006-0.17609\left(\frac{\mathrm{T}}{\mathrm{T}_{0}}\right)+0.03053\left(\frac{\mathrm{T}}{\mathrm{T}_{0}}\right)^{2} ; \mathrm{R}^{2}=0.996
\end{aligned}
$$

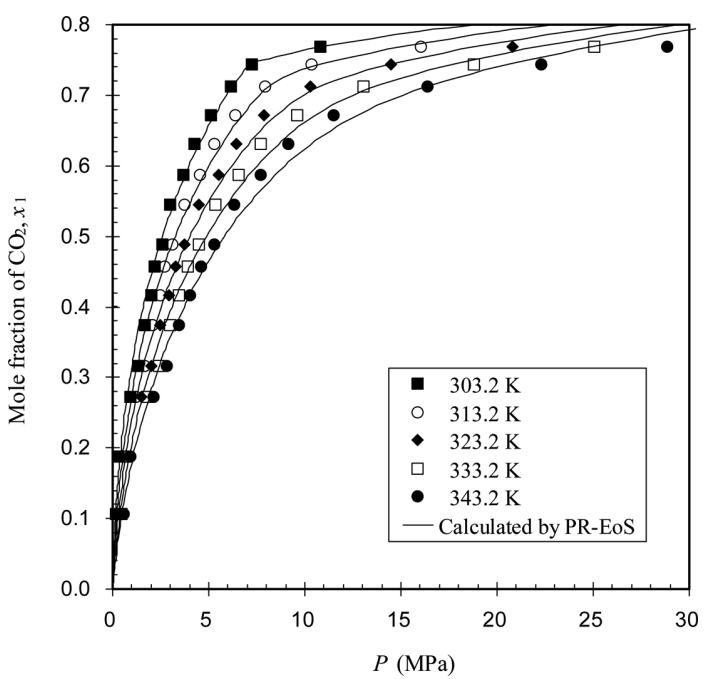

Fig. 6. Modeling results of the $\mathrm{CO}_{2}$ solubility in [bmpip] $\left[\mathrm{Tf}_{2} \mathrm{~N}\right]$ at several temperatures. The symbols are experimental data and the lines are the calculations by the PREoS model.

여기서, $T$ 의 단위는 $\mathrm{K}$ 이며 $T_{0}=298.15 \mathrm{~K}$ 이다.

본 연구에서 수행한 열역학적 모델링 결과를 Fig. 6 에 선으로 나타내었고 Table 5에는 실험값과 상태방정 식에 의한 계산값 사이의 평균편차 $(A A D \%)$ 를 정리하 였다. 상태방정식을 이용한 상관 결과를 좀 더 면밀히 분석한 결과, $303.2 \mathrm{~K}, 313.2 \mathrm{~K}$ 및 $323.2 \mathrm{~K}$ 의 온도에 서는 $2 \mathrm{MPa}$ 이하의 낮은 압력에서 실험값과 비교적 큰 편차를 보여주었으며, 반면에 높은 압력의 영역에

Table 5. Comparison of $\mathrm{CO}_{2}$ solubilities estimated at $5 \mathrm{MPa}$ for the $[\mathrm{bmpip}]\left[\mathrm{Tf}_{2} \mathrm{~N}\right]$ and $[\mathrm{bmim}]\left[\mathrm{Tf}_{2} \mathrm{~N}\right]$ ionic liquids

\begin{tabular}{ccccccc}
\hline \hline \multirow{2}{*}{ Ionic liquids } & \multirow{2}{*}{ Molar mass } & \multicolumn{2}{c}{$\mathrm{CO}_{2}$ solubilities at $303.2 \mathrm{~K}$} & & \multicolumn{2}{c}{$\mathrm{CO}_{2}$ solubilities at $323.2 \mathrm{~K}$} \\
\cline { 3 - 4 } \cline { 5 - 6 } & & In mole fraction & In molality & & In mole fraction & In molality \\
\hline$[$ bmpip $]\left[\mathrm{Tf}_{2} \mathrm{~N}\right]$ & 436.44 & 0.66 & 4.57 & & 0.57 & 3.02 \\
{$[$ bmim $]\left[\mathrm{Tf}_{2} \mathrm{~N}\right]$} & 419.36 & 0.69 & 5.28 & & 0.57 & 3.21 \\
\hline
\end{tabular}

Table 6. Optimum values of binary interaction parameters $\left(\mathrm{k}_{12}\right.$ and $l_{12}$ in Eqs. (4) and (6)) of the PR-EoS and deviations (AAD\%)

\begin{tabular}{|c|c|c|c|c|c|c|}
\hline $\begin{array}{ll}\text { Parameter } & \text { Temperature } \\
\end{array}$ & $303.2 \mathrm{~K}$ & $313.2 \mathrm{~K}$ & $323.2 \mathrm{~K}$ & $333.2 \mathrm{~K}$ & $343.2 \mathrm{~K}$ & Average \\
\hline $\mathrm{k}_{12}$ & 0.0722 & 0.0716 & 0.0705 & 0.0686 & 0.0661 & - \\
\hline $1_{12}$ & 0.0625 & 0.0590 & 0.0550 & 0.0513 & 0.0479 & - \\
\hline $\mathrm{AAD} \%{ }^{*}$ & 10.00 & 10.98 & 10.29 & 10.13 & 9.17 & 10.11 \\
\hline
\end{tabular}
between experimental and calculated values in equilibrium pressures for the $\mathrm{CO}_{2}+\left[\right.$ bmpip] $\left[\mathrm{Tf}_{2} \mathrm{~N}\right]$ system

*Average absolute deviation in percentage, which is defined as:

AAD $\%=\frac{1}{N} \sum_{m=1}^{N} \frac{\left|\mathrm{P}_{m}^{\text {calc }}-\mathrm{P}_{\mathrm{m}}^{\exp }\right|}{\mathrm{P}_{\mathrm{m}}^{\exp }} \times 100$ (N: number of data points).

Vol. 27, No. 2, 2014 
서는 상대적으로 작은 편차를 보여주었다. 한편 333.2 $\mathrm{K}$ 와 $343.2 \mathrm{~K}$ 의 온도에서는 중간 압력 영역에서는 실 험값과 작은 편차를 주었으나, 낮은 압력과 높은 압력 의 영역에서는 상대적으로 높은 편차를 보여주었다. 종합적으로는 전체 압력 범위에서 실험값과 계산값 사이에 $10 \%$ 정도의 편차를 보여주었다. 결론적으로 $\mathrm{PR}-\mathrm{EoS}$ 를 이용한 모델링 결과, 전체 압력 범위에서 실험 데이터를 완전히 만족시키지는 못하지만, 초임계 상태의 $\mathrm{CO}_{2}$ 압력까지의 넓은 압력 범위에서 이온성 액체에서의 $\mathrm{CO}_{2}$ 의 고압 용해도를 간편하게 모델링할 수 있다고 볼 수 있다. 전체 압력의 영역에서 모두 우 수한 모델링 결과를 얻기 위해서는 혼합법칙을 보완 할 필요가 있다. 다른 방법으로 낮은 압력의 범위와 높은 압력의 범위를 나누어서 상관시킨다면 좀 더 좋 은 모델링 결과를 얻을 수 있을 것으로 예상 된다.

\section{5. 결 론}

본 연구에서는 가변부피 투시 셀이 장착된 고압 평 형 장치를 사용하여 piperidinium 양이온과 $\left[\mathrm{Tf}_{2} \mathrm{~N}\right]$ 음 이온으로 구성되어 있는 [bmpip][Tf $\left.{ }_{2} \mathrm{~N}\right]$ 이온성 액체를 대상으로 지금까지 문헌에 보고된 바가 없는 이온성 액체에 대한 $\mathrm{CO}_{2}$ 의 용해도 데이터를 측정하였다. 낮 은 압력의 영역에서는 압력이 증가함에 따라 이온성 액체에 녹는 $\mathrm{CO}_{2}$ 의 용해도가 크게 증가하였으나, 높 은 압력의 영역에서는 압력이 크게 증가하여도 용해 도는 크게 증가하지 않았다. 다시 말해 $\mathrm{CO}_{2}$ 의 조성이 큰 경우 평형 압력은 급격히 증가하였다. 또한 같은 압력에서 비교할 때 온도가 증가함에 따라 이온성 액 체에서의 $\mathrm{CO}_{2}$ 의 용해도는 감소하였다. 본 연구에서 사용한 이온성 액체인 [bmpip][Tf $\left.\mathrm{T}_{2} \mathrm{~N}\right]$ 와 음이온이 같으 면서 imidazolium 종류의 양이온을 가진 [bmim][Tf $\left.{ }_{2} \mathrm{~N}\right]$ 에 대하여 두 이온성 액체가 갖는 $\mathrm{CO}_{2}$ 의 용해도를 같 은 온도에서 비교한 결과, 저압부터 고압까지의 압력 범위에서 두 이온성 액체가 보이는 $\mathrm{CO}_{2}$ 의 용해도는 압력에 관계없이 거의 유사하였다. 이는 두 이온성 액 체의 양이온에 붙어 있는 side chain의 길이가 같으며 두 이온성 액체가 가지고 있는 자유 부피가 거의 유 사하기 때문인 것으로 판단된다. 또한 두 이온성 액체 의 경우 양이온보타는 음이온이 $\mathrm{CO}_{2}$ 용해도에 더 우 세한 영향을 주기 때문인 것으로 보인다.

본 연구를 통해 얻은 용해도 실험 데이터를 PengRobinson 상태방정식에 상관시켜 열역학적 모델링을 수행한 결과, 온도와 압력의 영역에 따라 실험값과 상
태방정식에 의한 계산값과의 크거나 작은 편차를 보 여주었으며 종합적으로는 전체 압력 범위에서 실험값 과 계산값 사이에 $10 \%$ 정도의 편차를 보여주었다. Peng-Robinson 상태방정식을 이용한 열역학적 상관은 전체 압력 범위에서 실험 데이터를 완전히 만족시키 지는 못하였지만, 초임계 상태의 $\mathrm{CO}_{2}$ 압력까지의 넓 은 압력 범위에 걸쳐서 실용적인 모델링 결과를 주었 다고 판단된다.

\section{감사의 글}

본 연구는 한남대학교 2013학년도 교비학술연구비 의 지원으로 수행되었으며, 이에 감사드립니다.

\section{Reference}

1. M. Ramdin, T. W. de Loos and T. J. H. Vlugt, Ind. Eng. Chem. Res., 51, 8149-8177 (2012).

2. R. S. Haszeldine, Science, 325, 1647-1651 (2009).

3. G. T. Rochelle, Science, 325, 1652-1654 (2009).

4. H. Zhao, Chem. Eng. Commun., 193, 1660 (2006).

5. A. L Revelli, F. Mutelet and J. N. Jaubert, J. Phys. Chem. $B$, 114, 4600 (2010).

6. K. Kedra-Krolik, F. Mutelet and J. N. Jaubert, Ind. Eng. Chem. Res., 50, 2296 (2011).

7. J. E. Bara, T. K. Carlisle, C. J. Gabriel, D. Camper, A. Finotello, D. L. Gin and R. D. Noble, Ind. Eng. Chem. Res., 48, 2739 (2009).

8. M. Hasib-ur-Rahman, M. Siaj and F. Larachi, Chem. Eng. Processing, 49, 313-322 (2010).

9. F. Karadas, M. Atilhan and S. Aparicio, Energy Fuels, 24, 5817-5828 (2010).

10. M. J. Muldoon, S. N. V. K. Aki, J. L. Anderson, J. K. Dixon and J. F. Brennecke, J. Phys. Chem. B, 111, 90019009 (2007).

11. J. L. Anthony, J. L. Anderson, E. J. Maginn and J. F. Brennecke, J. Phys. Chem. B, 109, 6366 (2005).

12. J. Jacquemin, P. Husson, V. Majer and M. F. CostaGomes, J. Solution Chem., 36, 967 (2007).

13. P. J. Carvalho, V. H. Alvarez, J. J. B. Machado, J. Pauly, J. L. Daridon, I. M. Marrucho, M. Aznar and J. A. P. Coutinho, J. Supercrit. Fluids, 48, 99 (2009).

14. W. Ren, B. Sensenich and A. M. Scurto, J. Chem. Thermodyn., 42, 305 (2010). 
High-Pressure Solubility of Carbon Dioxide in 1-Butyl-3-methylpiperidinium Bis(trifluoromethylsulfonyl)imide Ionic Liquid 91

15. A. L. Revelli, F. Mutelet and J. N. Jaubert, J. Phys. Chem. B, 114, 12908 (2010).

16. E. K. Shin, B. C. Lee and J. S. Lim, J. Supercrit. Fluids, 45, 282-292 (2008).

17. E. K. Shin and B. C. Lee, J. Chem. Eng. Data, 53, 2728-2734 (2008).

18. J.-Y. Jung and B.-C. Lee, Analyt. Sci. Technol., 24(6), 467-476 (2011).

19. Y.-H. Jung, J.-Y. Jung, Y.-R. Jin, B.-C. Lee and I.-H. Baek, J. Chem. Eng. Data, 57, 3321-3329 (2012).

20. S. G. Nam and B.-C. Lee, Korean J. Chem. Eng., 30(2), 474-481 (2013).

21. Z. Lei, C. Dai and B. Chen, Chem. Rev, 114, 1289-1326 (2014).

22. R. Macias-Salinas, J. A. Chavez-Velasco, M. A. AquinoOlivos, J. L. Mendoza de la Cruz and J. C. SanchezOchoa, Ind. Eng. Chem. Res., 52, 7593-7601 (2013).

23. P. J. Carvalho and A. P. Coutinho, J. Phys. Chem. Lett., 1, 774 (2010).

24. M. R. Ally, J. Braunstein, R. E. Baltus, S. Dai, D. W. DePaoli and J. M. Simonson, Ind. Eng. Chem. Res., 43, 1296 (2004).

25. P. Scovazzo, D. Camper, J. Kieft, J. Poshusta, C. Koval and R. Noble, Ind. Eng. Chem. Res., 43, 6855 (2004).
26. A. Shariati and C. J. Peters, J. Supercrit. Fluids, 25, 109 (2003).

27. M. Yazdizadeh, F. Rahmani and A. A. Forghani, Korean J. Chem. Eng., 28(1), 246-251 (2011).

28. F. M. Maia, I. Tsivintzelis, O. Rodriguez, E. A. Macedo and G. M. Kontogeorgis, Fluid Phase Equilib., 332, 128 (2012).

29. X. Ji and H. Adidharma, Fluid Phase Equilib., 293, 141 (2010).

30. L. F. Vega, O. Vilaseca, F. Llovell and J. S. Andreu, Fluid Phase Equilib., 294, 15 (2010).

31. Guide to the Expression of Uncertainty in Measurement, International Organization of Standardization (ISO), Geneva, Switzerland (1995).

32. J. M. Prausnitz, R. N. Lichtenthaler and E. G. de Azevedo, Molecular Thermodynamics of Fluid-Phase Equilibria, 3rd ed., Prentice-Hall, NJ, 1999.

33. J. O. Valderrama, L. A. Forero and R. E. Rojas, Ind. Eng. Chem. Res., 51, 7838-7844 (2012).

34. Winnick, J., Chemical Engineering Thermodynamics, John Wiley \& Sons, New York, NY, 1997, pp. 451-463.

35. IMSL Math/Library: Fortran Subroutines for Mathematical Applications, Vol. 2, Visual Numerics, Inc., 1994. 